\title{
11 \\ FROM HINDU RASHTRA TO HINDU RAJ? A DE FACTO OR A DE JURE ETHNIC DEMOCRACY?
}

\author{
Christophe Jaffrelot
}

India was long considered a fine example of liberal parliamentary democracy among countries of the South. In addition to a strong legislature and judiciary, as well as a vibrant free press, political pluralism was nourished by federalism and cultural diversity, both linguistic and religious.

It is the erosion - even the obliteration - of the country's religious diversity that this chapter describes. This evolution calls into question India's secularism, a system for managing relations between state and religion that differs from what is known as laicité in France, for instance. While in France the state is supposed to have no connection with religion, in India, the republic's institutions acknowledge that religion has a perfectly legitimate place in the public sphere. What secularism and laïcité have in common, however, is the rejection of the dominance of any one religion in that sphere.

It is this very principle that is being challenged by the Hindu nationalist movement, its matrix, the Rashtriya Swayamsevak Sangh (Association of National Volunteers - RSS) and its main political force, the Bharatiya Janata Party (Indian People's Party - BJP) which rose to power in 2014. Although this party was already at the helm of India's government from 1998 to 2004, this was the first time it enjoyed an absolute majority in the lower house of parliament, putting it in a position to implement its agenda.

This agenda derives directly from its ideology, Hindutva, which was codified nearly a century ago, in the footsteps of European ethnic nationalisms - even emulating them (Jaffrelot 1996). Like them, it accords a predominant role to the majority community, made up of socalled sons of the soil, over the minorities. For adherents of Hindutva, Hindus embody the Indian nation, and minorities whose religion originated abroad (Muslims and Christians) are mere outsiders who must assimilate by adopting the majority/majoritarian culture.

After the BJP victory in 2014, this programme was primarily implemented by civil-societybased organisations within the Hindutva movement that act as vigilante groups specialized in cultural policing. But since Narendra Modi's re-election to the prime ministership in 2019, the de facto ethnicization of India's democracy has taken on a new dimension. The BJP has in fact passed more and more laws at both the level of the states it governs and at the central government level, so that India is tending to become a de jure ethnocracy. India is thus in the process not only of building a Hindu Rashtra, a Hindu nation, but also a Hindu Raj, a Hindu state. 


\section{A de facto ethnic democracy or the rise of Hindu vigilantism (2014-2019)}

If the notion of ethnic democracy, theorized by Sammy Smooha, sounds like a contradiction in terms - in that democracy is theoretically based on the values of individualism - it is because it describes the contradictions of the regime where it originated: the state of Israel. Certain pillars of democracy there have shown great resilience: rather free and fair elections are held at regular intervals, the judiciary's relative independence lends credibility to the rule of law, and a fairly free press provides a forum for criticism, all this in the context of a certain degree of pluralism. But not all citizens enjoy the same rights: as Israel is officially "the state of the Jews," this population imposes the symbols of its identity, lifestyle and social and political domination on the country's minorities. Smooha points out that even if this power relationship is enshrined in the law, it is augmented through practices, most discrimination being rather covert, arising from (sometimes) unwritten laws that have unintended effects, such as conditioning eligibility for Israeli state benefits on military service - which is performed mainly by Jews (Smooha 2002).

In India as well, during Narendra Modi's first term, the Hinduization of the public sphere developed to the detriment of champions of secularism and of minorities. The first victims of Hindu nationalists were none other than intellectuals, who were taken to task for their "liberalism" (which has become a derogatory term). The Hindu nationalists' preferred targets were highly regarded universities - such as Jawaharlal Nehru University in New Delhi - and progressive NGOs: Hindutva apologists were placed at the head of university administrations, and organizations were deprived of contributions from abroad (through the resurrection of a law that had been passed in 1976 during the Emergency (Jaffrelot and Anil 2021), the Foreign Contribution (Regulation) Act), forcing several of them to shut down operations.

This evolution has also resulted in calling into question the national narrative and especially the way the history of India had been taught in school. Textbooks have been rewritten so as to discard the idea of "Aryan invasions" (which deprived Hindus of their "sons of the soil" status), to depict the Muslim conquests and reign in a particularly violent light (ignoring the role of Sufism in mass conversions to Islam and a large degree of cultural syncretism) and, last, to tone down the role of great figures of contemporary history (starting with Nehru, and even Gandhi) and replace them with their own heroes, whose names have moreover been given to many avenues, universities, airports and so on.

Together with this Hinduization, which was also reflected in the noticeable presence of several Hindu dignitaries in the highest echelons of government - as can be seen in the choice of a priest, Yogi Adityanath, to head Uttar Pradesh following the BJP victory in the 2017 elections in that state - have been mounting discriminatory practices against Christian and Muslim minorities. Vigilante groups in charge of harassment campaigns sometimes only had very loose connections with the BJP - enabling it to preserve an aura of respectability - but they were nevertheless part of the Sangh Parivar which is the network that the RSS (known as the "Sangh") has created and that it coordinates as a "family" (parivar). Among these groups, the Bajrang Dal (BD), established in 1984, warrants special mention due to its involvement in heavy-handed operations such as, in 1992, the demolition of the Babri Masjid, the famous mosque built by Mughal emperor Babur in 1528 in Ayodhya that Hindu nationalists claim to have been erected on the birthplace of Lord Ram, where a Hindu temple allegedly stood and that they wished to rebuild. The Bajrang Dal had painstakingly recruited thousands of activists among a Hindu youth hard hit by unemployment, lacking self-esteem and for whom defence of Hinduism gave meaning to their lives, and even a job (Jaffrelot 2009).

This group, like so many others, became involved as of 2014 in campaigns targeting, by turn, mixed marriages, religious conversions and defence of the sacred cow. In the fall of 2014, 
Table 11.1 Cow-related violence in India, 2012-18

\begin{tabular}{|c|c|c|c|c|c|c|c|}
\hline Year & 2012 & 2013 & 2014 & 2015 & 2016 & 2017 & 2018 \\
\hline Incidents & 1 & 2 & 3 & 13 & 30 & 43 & 31 \\
\hline Victims & 2 & 0 & 11 & 49 & 67 & 108 & 57 \\
\hline Deaths & 0 & 0 & 0 & 11 & 9 & 13 & 13 \\
\hline
\end{tabular}

Source: IndiaSpend.org, "Database on Bovine-Related Violence (from January 2010 to September 2, 2017)” (https://docs.google.com/spreadsheets/d/13REUhD4fW6olOy_ SjobWQRA1qQg3VY1pp87XMRJwJW4/pubhtml. Last accessed April 9, 2018). This online publication ceased to exist in 2017 but it set up another website dedicated to lynching victims in connection with sacred cows called "Hate Crime: Cow-related Violence in India" (http://lynch. factchecker.in). This publication also ceased to exist in 2018 when I could access it one last time.

in a campaign against so-called love jihad, BD members went on prowls to protect young Hindu women from Muslims supposedly out to woo them and trick them into marrying and converting. A remarkable example of investigative journalism by two news websites, Cobrapost and Gulail.com, bears testimony to the intimidation techniques used by Hindu nationalists (Cobrapost 2015). This strongarm intimidation campaign targeted Muslims as much as young Hindu women, even when they were of age and wanted to take a Muslim (or a Christian) for their husband.

Regarding conversions, the effort to fend off Muslim and even more so Christian proselytizing resulted not only in violence (churches desecrated, priests and nuns attacked, etc.), but also in reconversion operations called ghar wapsi (homecoming). The initiative for this campaign lies directly with the RSS, which gathered together 1,200 of its members and sympathizers in Nagpur on November 7 and 9, 2014 (a few weeks after the campaign against "Love Jihad" was launched). The Sangh branch responsible for carrying out the actual conversion operations was the Dharm Jagran Samiti (Religious Awakening Committee). The RSS assigned 58 pracharak (full-time cadres) to the task, a considerable number for such a campaign (Yadav 2018).

As for cow protection, which was actually extended to all bovines, it primarily took the form of inspecting trucks suspected of transporting cattle to the slaughterhouse. Many of the drivers intercepted on the roads of India were severely beaten by vigilantes armed with cricket bats or field hockey sticks and even knives and firearms. The use of firearms has developed considerably in recent years. The Gau Raksha Dal (cow protection movement) emblem is composed of two AK-4 type weapons wreathing the head of a calf. IndiaSpend estimates that in 2017 there were 43 bovine-related incidents, compared to 30 in 2016, 13 in 2015, 3 in 2014, 2 in 2013 and 1 in 2012. Twenty-four out of the 28 victims during the period between January and June 2017 were Muslim (Abraham and Rao 2017), probably the standard ratio.

Several dozen Muslims died of their injuries in lynchings, enough of them for the Supreme Court finally to turn its attention to the matter in 2018. The judges blamed mobs and social media (first and foremost WhatsApp) through which false information was spread to provoke and coordinate assaults (Ananthakrishnan 2018). By doing so, the Supreme Court shunned its responsibilities by not seeking the guilty parties, as Raheel Dhattiwala (2018) has pointed out, and played the game of the Hindu nationalists, who systematically legitimate anti-Muslim violence by referring to emotions and, more specifically, the "religious sentiment" that fuels champions of the faith who can quickly whip themselves up into a fury for a sacred cause.

The cultural policing carried out by Hindu vigilantes is a good illustration of the Hindu nationalist movement's modus operandi and in particular of its historical matrix, the RSS. The RSS in fact assigned itself the mission of extending its influence over the entire society, 
establishing its presence by setting up branches (shakha) in all of India's towns and villages. This long-term project, by which the RSS sought to conquer India from the bottom up via unrelenting social and ideological engineering to bring about a Hindu Rashtra (Hindu nation), moreover reflects a major characteristic of the Hindu tradition, which has never valued the state, but instead the social order born out of the caste system, an orthopraxy of which the upper castes were the custodians. RSS leaders, all of whom until fairly recently were of the Brahmin caste, had long adhered to this model that implied enforcing their order at a more societal than a political - or in any event bureaucratic - level. But recent developments indicated a certain evolution regarding this crucial element.

\section{Towards a de jure ethnic democracy, or the triumph of state vigilantism (2019-)}

The shift from a bottom-up strategy starting at the grassroots level to a top-down strategy involving the public authorities first became apparent in states governed by the BJP. In the mid-2010s, Maharashtra, Haryana and Gujarat all toughened their cow protection laws. In Maharashtra, it was now prohibited to slaughter not just cows but also many other bovines. Even possession of beef was outlawed (Daniyal 2015). The crime became punishable by up to a five-year prison sentence and a heavy fine. In Gujarat, even more drastic legislation in the matter was accompanied by similar decisions in major cities to prevent the religious mixing of populations: in some districts/neighbourhoods, the members of one religious community were permitted to sell or rent real estate only to people of the same religion (Jaffrelot and Laliwala 2018). Such regulations provided a legal basis for those who wanted to combat "land jihad," a new dimension in vigilante practices that aimed to dissuade Hindu landowners by force (or by intimidation) from renting or selling property to Muslims in mainly Hindu areas. These practices, together with new rules and the adverse effects of communal riots - which, in 2002, descended into a pogrom in Gujarat - have fostered the formation of veritable ghettos where Muslims both rich and poor are crammed together for lack of available housing elsewhere and for their own safety (Laliwala et al. 2021).

After the 2019 elections, several BJP-governed states announced the passing of laws officializing the practice of "love jihad" by making it virtually impossible for Hindu women to marry men of another faith. In Uttar Pradesh, the first state to go through with such legislation in 2020, marriages were impeded by the police on the pretext that the husband-to-be intended to convert his wife-to-be (a "crime" punishable by a ten-year prison term) (Rashid 2020). BJP leaders made no secret that they now wanted to impose their perception of what was good for society, not only by resorting to street vigilantism, but by the law, that is state vigilantism (Jaffrelot 2020). The home minister of Madhya Pradesh, another BJP-ruled state - along with Gujarat, which passed an "anti Love-Jihad" law - declared: "Any love that heads towards jihad, we will oppose it. Any love that offends our sentiments, we will oppose it" (Siddique 2021).

The most independent media outlets have reported on the growing unease among existing interfaith marriages in which the Muslim party seeks to conceal his/her given name or surname to mask his/her religious identity (an evolution also evidenced by the trend of Muslim couples to give their children non-Muslim-sounding names).

In enforcing this policy to prevent interfaith marriage, the police now play the role previously assumed by vigilante groups - further evidence of the shift from a bottom-up to a topdown strategy mentioned above, although the latter has not entirely replaced the former. This progression towards a Hindu Raj is not being accomplished solely through state-level legislation: it can also be noted at the national level. 
In 2019, it was reflected in the passage of a constitutional amendment to article 370 and an amendment to the Citizenship Act (CAA). The former revoked the autonomy previously enjoyed by Jammu and Kashmir - which in the process lost its status as a state to become merely a Union Territory (UT) and wound up split in two when Ladakh was made another UT. This reform was justified by the government by the strength of Islamist separatism and the economic underdevelopment affecting the province - in spite of the empirical evidence which said otherwise (Dreze 2019). It was interpreted locally as an attempt to assimilate the only region with a Muslim majority into a Hindu-dominated Indian Union. Not only after the province became a Union Territory, its police now reported directly to the central government, but along with Art. 370, Art. 35A was also abolished. Under this article, the assembly of Jammu and Kashmir was empowered to define "permanent residents" of the state and to reserve for them certain rights, including the right to own land in the state and to have access to government jobs. Article 35A was one of the laws that was repealed after the abrogation of Art. 370 and then, in March 2020, the Modi government replaced "permanent residents" with domiciles of Jammu and Kashmir by a new provision: anyone who had lived in the region for 15 years, studied there for seven years or written school board examinations was eligible to own land and hold government jobs.

The Kashmiris' fear of losing their land was stoked by the fact that land had already started to be reserved for outside investors and the armed forces: $70 \%$ of the new mining contracts have gone to non-locals (Siddiq 2020) and two laws (The Control of Building Operations Act, 1988, and the Jammu and Kashmir Development Act, 1970) were amended in July 2020 to introduce some "special dispensation for carrying out construction activities in Strategic Areas" - in other words, some land could be easily confiscated and transferred to the army for its own use, a process that has started already (Zargar and Chakravarty 2020). Furthermore, in July 2020 as well, the government decided that army and paramilitary forces would not require a No Objection Certificate from its home department "for acquisition or requisition of land in favour of the Army, B[order] S[ecurity] F[orce], CRPF and other similar organizations" (Iqbal 2020).

These measures reflected the will of the BJP (which has never resigned itself to the federal structure of India's institutions) to transform India into a unitary nation-state (Aiyar and Tillin 2020) and to change the demographic balance in the only Muslim-dominated territory. Indeed, a few days after the abrogation of Art. 370, Narendra Modi declared during his August 15 address: "Today, as I address the nation from the Red Fort, I can proudly say that every Indian today can speak of One Nation, One Constitution ..." (Business Today 2019).

The Citizenship (Amendment) Act turned out to have also momentous consequences. The law, advertised as proof of the Indian government's concern for victims of religious persecution in the region, shows the selective nature of such concern. Indeed, only non-Muslim victims from Bangladesh, Afghanistan and Pakistan were eligible to become Indian citizens through this law - via an expedited six-year procedure. Rohingyas, Shias, Ahmadis and Hazaras could not claim refugee status, nor could the victims of religious persecution from Sri Lanka, Tibet, Myanmar or Nepal. The law sowed panic among many Indian Muslims who were afraid they would not be in a position to prove their Indian nationality for lack of documentation, something that is very hard to produce in a country that never had a systematic register of citizens. This fear was fuelled by the establishment of the National Register of Citizens in the state of Assam, where there was a large number of Muslim migrants from Bangladesh. The fact that CAA and NRC worked in tandem was made clear by Amit Shah himself when he said during a press conference in West Bengal - the video of which was posted on the BJP's YouTube page in April 2019: "Understand the chronology [...] First the Citizenship (Amendment) Bill will 
come, all the refugees will be given citizenship, and after that the NRC will be prepared" (ICF Team 2020). This meant that the non-Muslim undocumented migrants would gain access to some sort of naturalization procedure before the NRC was put in place and that this NRC could only affect Muslims. Moreover, in September 2019, the RSS chief, Mohan Bhagwat made it clear that "No Hindu will have to leave over NRC" (The Telegraph 2019).

Hindu militant WhatsApp groups gradually translated this message into their own idiom: the combination of the CAA and the NRC was a tool to "kick Muslims out of India." A journalist who had infiltrated these groups explains that "One major theme that a majority of the messages echo is that bringing the CAA and, then, the NRC, will automatically imply that India's Muslim population will be reduced. [...]" They list a 'four-step' process for India becoming a Hindu nation - starting with the CAA, followed by the NRC, then a law to control population, ultimately followed by a Uniform Civil Code.

In reaction to the CAA, thousands of demonstrators took to the streets in the fall of 2019. Most of them were Muslims who were afraid of becoming "doubtful citizens," but many students also took part in sit-ins, including in Shaheen Bagh, Delhi - by far the bestknown place of protest where the Indian Constitution was eulogized in countless debates and speeches.

In reaction to this mobilisation, however, Uttar Pradesh was the state that saw the unleashing of maximum police violence in late 2019. The campus of Aligarh Muslim University, where the protest had gained momentum, was the first target. On December 15, the police and members of the Rapid Action Force (RAF) forcefully entered the university campus, breaking the iron gate at 10 p.m., and assaulted students. One student's hand had to be amputated (Srivastava 2012). The AMU vice chancellor claimed (The Hindu 2020), retrospectively, that he had invited the police to intervene, but why, in that case, did they break the main gate? Elsewhere in Uttar Pradesh, the police used real bullets to crack down on demonstrators, leaving 24 dead in the space of a few days (Pandey 2020) - out of the 31 casualties recorded throughout India (Sen and Singaravelu 2020). In addition, a large number of young Muslims, including minors, were arrested - and in many cases tortured (Indo-Asian News Service 2019).

But early in 2020 the epicentre of the crackdown was in Delhi, a state where the CAA was exploited by the BJP in the context of the election campaign that began in December 2019 and intensified in January 2020. There, too, the police - under the direct supervision of Narendra Modi's home minister, Amit Shah - conducted the crackdown. While Delhi is a state of the Indian Union, it does not enjoy the same autonomy as full-fledged states and, in particular, the police report directly to the central government's Home Ministry. First targeted was Jamia Milia University in December (The Economic Times 2019) where activists and the police joined forces. As the police habitually destroy CCTV cameras, their involvement in the clashes is attested primarily by amateur videos posted on social media.

The communal riots that took place in February 2020 in North-East Delhi - a very densely populated district where, according to the 2011 census, Muslims represented more than 29\% of the population and Hindus, about $68 \%$ - were primarily due to the BJP's reaction to the anti-CAA movement in the context of the state elections. During the election campaign, BJP leaders targeted protesters against the CAA in Delhi - not only in Shaheen Bagh, but elsewhere in the city, including in the North-East, where many sit-ins were held - in order to polarize voters along communal lines. A member of the Modi government, Anurag Thakur, raised a slogan in an election rally that was to be repeated many times: "Desh ke ghaddaron ko, goli maaron saalon ko" (Shoot down the rascals/the traitors to the country) (Shamshad et al. 2020, p. 27). 
On February 11, 2020, the BJP had a rude shock as only eight of its candidates, out of 70, could win a seat, against 62 for the Aam Aadmi Party of Arvind Kejriwal. BJP cadres wanted to take revenge (Mubayi 2020). Their post-election meetings were as aggressive as the pre-election ones. On February 23, 2020, Kapil Mishra, a BJP candidate who had lost the election in February 2020, led a provocative rally in North-East Delhi. Mishra addressed the gathering in the presence of the Deputy Commissioner of Police for North-East District, Ved Prakash Surya, who was standing right next to him in full riot gear. It projected an unexampled visual by associating an expert in communal provocation and a custodian of law and order. Thousands of assailants, led by Hindu nationalist cadres, including BJP former or sitting MLAs and municipal councillors (Singh 2020; Menon and Iyer 2020) forcibly entered houses to attack men and women (Shamshad et al. 2020, pp. 61-69); 600 houses were burnt (Alavi 2020) and shops looted with a remarkably accurate selectivity, as adjacent houses and shops were spared when they belonged to Hindus (Express News Service 2020); markets were razed to the ground as well (Shamshad et al. 2020); mosques were systematically targeted - they were looted, desecrated and burnt (Mody 2020). A businessman who happened to be a BJP cadre said that his factory had been burnt because he had a "Muslim name," suggesting that, like in Gujarat in 2002, the rioters were using lists of residents - maybe the voters lists (Express News Service 2020). In Tyre Market the fire brigade, which had rushed to the place, was attacked physically (Shamshad et al. 2020, p. 48). After four days, the official toll was 55 dead, including 13 persons with non-Muslim names (Shamshad et al. 2020, pp. 111-118).

While Hindu nationalists initiated the riots, the police played an important role in them. Not only did they not come to the rescue of the Muslims, but they took an active part in the violence on many occasions. In the complaints filed subsequently, victims declare that the police also incited the activists to attack them (Singh 2020). Police officers also took part in the looting and destruction of mosques, sometimes while chanting "Jai Shri Ram” (Shroff 2020a; 2020b). Possibly in reaction to the attitude of the police, two security personnel were killed during the riot: Ankit Sharma, an Intelligence Bureau staff member (Bhardwaj 2020), and Police Constable Ratan Lal. The New York Times, whose journalists emphasize that "Delhi's Police turned against Muslims," mentions the fact that not only one police officer was killed but that 80 others were injured, especially when Muslim protesters outnumbered the police (Gettleman et al. 2020). Seemingly as a result, the police directly assaulted Muslims even more brutally. One of these attacks, on February 24, 2020, was filmed and the videos went viral on social media. They showed five men beaten by the police in the Kardam Puri Pulia area and told to chant the national anthem. One of them, Faizan, died (Yadav 2020). In other places, the police were pelting stones at the Muslim mob along with Hindu rioters, or, as in Chand Bagh "the police were encouraging the mob to carry out the riots" (Shamshad et al. 2020, p. 74). The police also took part in the looting and destruction of mosques and madrasas - usually after destroying the CCTV cameras (Shamshad et al. 2020, pp. 40, 45). Not only could the victims not file a complaint, but they were accused of being responsible for the violence itself (Lalwani 2020) - whereas no FIR has been registered against Hindu activists who took part in the riots, BJP leaders who made provocative speeches or policemen who were seen attacking Muslims on videos. The detailed report filed by the fact-finding committee set up on March 9, 2020 by the Minorities Commission of the state of Delhi and from which much of the information above was drawn was not even used by the authorities. Not only that, but the chairman of the Delhi Minorities Commission, Zafarul-Islam Khan, was accused of sedition in April 2020 because of a Facebook post (Bedi 2020).

Instead, the narrative promoted after the Delhi riots by the police and the BJP government both representing two sides of the same coin, that is, the state - consisted in exonerating the 
police and accusing the Muslims. On March 10, Amit Shah, the Home Minister to whom the Delhi police report directly, congratulated himself that the police succeeded in controlling the riots "within 36 hours," "not allowing the riots to spiral" (The Wire 2020). Shah concluded that these "riots were 'pre-planned' conspiracy" and that it "will be a lesson for the country on what befalls those who indulge in rioting" (The Wire 2020).

This enabled the police to resort to a stringent anti-terror law, the Unlawful Activities Prevention Act, 2019 (UAPA), under which a detainee may have to await trial for up to two years and not be released on bail or be apprised of the charges against him/her for six months. It is noteworthy that the Narendra Modi government had just amended the law to make it possible to label as "terrorists" isolated individuals and not solely men and women belonging to an organization.

\section{Conclusion}

The trajectory of India's democracy since 2014 has led it not only to renege on its traditional secularism by establishing a de facto ethnic democracy during Narendra Modi's first term, but also to embark on the path of a de jure ethnic democracy since 2019, the year in which the $\mathrm{BJP}$, on the strength of its electoral success, set out to transform the law and the Constitution.

This evolution drew on greater recourse to the police, who have taken up the task of Hindu vigilante groups, transforming social violence into state violence. The officialization of this new power relationship came out in the open when the judge of the Delhi High Court, Justice Muralidhar, who was seeking to hold the police to account, was transferred to Chandigarh, removing the only remaining obstacle in the way of pursuing the violence (Sachdev 2020).

But in other circumstances, Indian judges have sided wholeheartedly with the authorities. The Supreme Court thus did not deem it worthwhile to examine the cases of either the abolition of article 370 of the Constitution or the CAA, despite the large number of petitions. It even reactivated implementation of the NRC in Assam and arbitrated in favour of building a Hindu temple in Ayodhya. Reinforced by the legalization of a plan that until then enjoyed popular legitimacy only, Narendra Modi officiated, as a priest, over the laying of the temple's cornerstone. If the de jure ethnic democracy that India is becoming actually increasingly resembles a theocracy, the attitude of the judges - compounded by the decline of other institutions including Parliament (Jaffrelot and Jumle 2020) and the Election Commission (Ostermann and Ahuja 2018) - calls into question the very qualifier "democracy." In just a few years, India has come to lengthen the list of countries whose authoritarianism dons a pluralist guise at election time, with several parties taking part, but the fairness of these elections is increasingly doubtful. In fact, Modi's India increasingly fulfils the criteria of ethnocracy. This concept introduced by Donald Horowitz (Horowitz 1985, 499-500) has been elaborated upon, once again, by Israeli social scientists. Oren Yiftachel applied it to his country in the late 1990s in an article that minimized the democratic side of the regime and emphasized, on the contrary, the domination of the state and the capture of its resources by a majority community at the expense of minorities (Yiftachel 1997; 2006).

If India can now be considered as an ethnocracy because of its democratic decline and the growing assertion of Hindu nationalism, it can be compared more easily to other South Asian countries, including Sri Lanka, Bangladesh and Pakistan. The parallel with the "country of the pures" is striking in more than one way. First, minorities are marginalized not only in all sites of power, but also physically, as evident from the ghettoization process experienced by Hindus, Christians and Ahmadis that runs parallel to what is now obvious in the case of Indian Muslims. Minorities should not mix either in terms of intermarriages. However, in Pakistan, minorities 
have separate electorates, whereas in India they vote with the Hindu majority. Secondly, red lines are crystallizing on both sides. In Pakistan, the anti-blasphemy law has become sacrosanct, whereas in India, to pay allegiance to the cow and to Lord Ram has not become part of the laws of the Republic (but some BJP-ruled states have passed acts in this direction already). Thirdly, the political leaders who do not defend the majority community are presented by the rulers as illegitimate and anti-national. In Pakistan, politicians are not supposed to express compassion for Ahmadis publicly and in India Modi has disqualified Sonia Gandhi because she was a Christian, according to him, and the Manmohan Singh government - which he called the "Delhi Sultanate" - because it allegedly was pro-Muslim (Jaffrelot 2013; 2016). In both countries, national-populist leaders, including Imran Khan and Narendra Modi, have exploited the fear and the anger of ethno-religious majorities in this context. Their mobilization techniques illustrate how, according to Arjun Appadurai, "predatory identities" exploit "the fear of small numbers," that comes from the "anxiety of incompleteness" that afflicts ethnic communities when they do not coincide with the nation-state (Appadurai 2018). Imran Khan and Narendra Modi brought their communities from fear to outrage and anger, a theme that all populists exploiting social frustration have played on in the early twenty-first century. In his book on the role of anger in the rise of nationalism, Pankaj Mishra draws examples as much from the nineteenth century as from the present (Mishra 2018): anger arises from fear itself because majorities are not supposed to feel vulnerable; and this anger can be turned towards the politicians who do not defend enough the majority community because of their cosmopolitanism or for other reasons.

Last but not least, India and Pakistan converge today towards similar forms of authoritarianism because of the role the "deep state" plays in both countries. While the army and the security apparatus at large have occupied the driver's seat for decades in Pakistan - even when civilians govern the country (but do not rule) - a similar scenario is unfolding itself in India: the Hindu nationalist movement is, indeed, infiltrating an increasingly large number of institutions, including the bureaucracy, the judiciary, the intelligence services and the army.

\section{Nota Bene}

This article draws on certain chapters of my book, Modi's India. Hindu Nationalism and the Rise of Ethnic Democracy, Princeton, Princeton University Press, and New Delhi, Westland, 2021, which the interested reader might refer to for further information. There are few footnotes for this reason.

\section{Bibliography}

Abraham, Delna and Ojaswi Rao, 2017, "86\% killed in cow-related violence since 2010 are Muslim, 97\% attacks after Modi govt came to power,' Hindustan Times, July 16. URL: www.hindustantimes.com/indianews/86-killed-in-cow-relat. . .after-modi-govt-came-to-power/story-w9CYOksvgk9joGSSaXgpLO.html Last accessed March 26, 2018.

Aiyar, Yamini. and Louise Tillin, 2020, “'One nation,' BJP, and the future of Indian federalism," India Review, 19(2), March-April, pp. 117-135.

Alavi, Shams Ur Rehman, 2020, "Delhi Horror: Documenting the organised mob violence and killings in India's national capital,” NewsBits, March 4. URL: www.newsbits.in/delhi-horror-documentingthe-organised-mob-violence-and-killings-in-indias-national-capital Last accessed September $1,2020$.

Ananthakrishnan, Gopalakirshnan, 2018, "Mobocracy can't be the new normal, get a law to punish lynching: SC to Govt," The Indian Express, July 3. URL: https://indianexpress.com/article/india/ cji-condemns-lynchings-across-country-asks-parliament-to-make-new-law/ Last accessed September 28, 2020. 


\section{Christophe Jaffrelot}

Appadurai, Arun, 2006, Fear of Small Numbers. An Essay on the Geography of Anger, Durham: Duke University Press, pp. 51-53.

Bedi, Aneesha, 2020, "Delhi Minorities Commission chief charged with sedition for 'provocative' social media post," The Print, May 2. URL: https://theprint.in/india/delhi-minorities-commission-chiefcharged-with-sedition-for-provocative-social-media-post/413112/ Last accessed September 1, 2020.

Bhardwaj, Ananya, 2020, "IB staffer Ankit Sharma, killed in Delhi riots, was stabbed 12 times \& had 33 blunt injuries," The Print, March 14. URL: https://theprint.in/india/ib-staffer-ankit-sharma-killedin-delhi-riots-was-stabbed-12-times-and-not-400-times/380720/ Last accessed September 1, 2020.

Business Today, 2019, “Independence Day: Full text of PM Modi’s address to nation,” Business Today, August 15. URL: www.businesstoday.in/current/economy-politics/independence-day-pm-modiaddress-nation-full-text-speech-15-august-red-fort/story/372903.html Last accessed September 3, 2020 .

Cobrapost, 2015, “Operation Juliet: Busting the bogey of 'Love Jihad',' October 4. URL: http:// cobrapost.com/blog/operation-juliet-busting-the-bogey-of-love-jihad-2/900 Last accessed April 9, 2018.

Daniyal, Shoaib, 2015, "Maharashtra's beef ban shows how politicians manipulate Hindu sentiments around cow slaughter," Scroll.in, March 3, 2015. URL: https://scroll.in/article/711064/maharashtrasbeef-ban-shows-how-politicians-manipulate-hindu-sentiments-around-cow-slaughter Last accessed May 2, 2021.

Dhattiwala, Raheel, 2018, “'Blame It on the Mob' - How Governments Shun the Responsibility of Judicial Redress," The Wire, August 17. URL: https://thewire.in/communalism/mob-violencelynching-government-legal-process Last accessed September 28, 2020.

Dreze, Jean, 2019, "Article 370 helped reducing poverty in Jammu and Kashmir," National Herald, August 9. URL: www.nationalheraldindia.com/india/economist-jean-dreze-jandk-more-developed-thangujarat-special-status-helped-reducing-poverty Last accessed May 2, 2021.

Express News Service, 2020, "Factory burnt, BJP man says ignored by party because 'I have Muslim name'," The Indian Express, March 5. URL: https://indianexpress.com/article/cities/delhi/factoryburnt-bjp-man-says-ignored-by-party-6299749/ Last accessed September 1, 2020.

Gettleman, Jeffrey, Sameer Yasir, Suhasini Raj and Hari Kumar, 2020, "How Delhi's Police Turned Against Muslims," The New York Times, March 12. URL: www.nytimes.com/2020/03/12/world/ asia/india-police-muslims.html Last accessed September 1, 2020.

Horowitz, Donald, 1985, Ethnic Groups in Conflict, Berkeley, University of California Press.

ICF Team, 2020, "Assam and CAA," NewsClick, March 12. URL: www.newsclick.in/Assam-CAATimeline-Assam-Accord-1985-Present Last accessed May 2, 2020.

IndiaSpend, 2018, "Hate Crime: Cow-related Violence in India.” URL: http://lynch.factchecker.in Last accessed, March 26, 2018.

Indo-Asian News Service, 2019, “21,500 booked for violence in Kanpur," India Today, Dec. 24. URL: www.indiatoday.in/amp/india/story/21-500-booked-for-violence-in-kanpur-1631048-201912-24 Last accessed May 2, 2020.

Iqbal, Naveed, 2020, "J\&K: Army, CRPF, BSF will no longer require NOC for land acquisition," The Indian Express, July 28. URL: https://indianexpress.com/article/india/jk-army-crpf-bsf-will-nolonger-require-noc-for-land-acquisition-6526708/ Last accessed September 3, 2020.

Jaffrelot, Christophe and Sharik Laliwala, 2018, “The segregated city," Indian Express, May 26. URL: https://indianexpress.com/article/opinion/columns/muslims-in-india-hindus-jains-gujaratlove-jihad-5191304/ Last accessed May 2, 2021.

Jaffrelot, Christophe and Pratinav Anil, 2020, India's First Dictatorship - The Emergency, 1975-77, London, Hurst; New York, Oxford University Press; New Delhi, HarperCollins.

Jaffrelot, Christophe and Vihang Jumle, 2020, "Bypassing parliament," The Indian Express, October 15. URL: https://indianexpress.com/article/opinion/columns/narendra-modi-government-parliamentlok-sabha-rajya-sabha-6725428/ Last accessed October 16, 2020.

Jaffrelot, Christophe and Pratinav Anil, 2021, India's First Dictatorship: The Emergency, 1975-1977, Oxford, Oxford University Press.

Jaffrelot, Christophe, 1996, The Hindu Nationalist Movement and Indian Politics, 1925 to the 1990s, New York, Columbia University Press; London, Hurst; New Delhi, Penguin India, p. 582 (updated edition in 1999).

Jaffrelot, Christophe, 2009, The Militias of Hindutva: Communal Violence, Terrorism and Cultural Policing, in L. Gayer and C. Jaffrelot (eds), Armed Militias of South Asia. Fundamentalist, Maoists and 


\section{From Hindu rashtra to Hindu raj?}

Separatists, London, Hurst; New York, Columbia University Press; New Delhi, Foundation Books, pp. 199-236.

Jaffrelot, Christophe, 2013, "Gujarat Elections: The Sub-text of Modi’s 'Hattrick' - High Tech Populism and the 'Neo-middle Class'," Studies in Indian Politics, 1(1), June, pp. 79-96.

Jaffrelot, Christophe, 2016, "Narendra Modi between Hindutva and subnationalism: The Gujarati asmita of a Hindu Hriday Samrat, India Review, 15(2), pp. 196 - 217.

Jaffrelot, Christophe, 2020, "On 'love jihad', BJP picks up baton from vigilante groups. Police, judicial apparatus have aided this move," The Indian Express, November 26. URL: https://indianexpress.com/ article/opinion/columns/love-jihad-law-india-bjp-7067013/ Last accessed May 2, 2021.

Laliwala, Sharik, Christophe Jaffrelot, Priyal Thakkar and Abida Desai, 2020, "Paradoxes of Ghettoization: Juhapura 'in' Ahmedabad,' India Exclusion Report 2019-20, February 16. URL: https:// spire.sciencespo.fr/hdl:/2441/1ni56132699n1r9hm18of0urkr/resources/2021-jaffrelot-paradoxes-ofghettoization-india-exclusion-report-2019-20.pdf Last accessed May 2, 2021.

Lalwani, Vijayta, 2020, "In Delhi violence investigation, a disturbing pattern: Victims end up being prosecuted by police," Scroll.in, May 23. URL: https://scroll.in/article/962526/in-delhi-violenceinvestigation-a-disturbing-pattern-victims-end-up-being-arrested-by-police Last accessed September 1,2020

Menon, Aditya and Aishwarya S. Iyer, "Delhi Riots Exclusive: BJP Councillor Led Mob, Claims 'Eyewitness'," The Quint, June 30. URL: www.thequint.com/news/politics/delhi-riots-bjpcouncillor-kanhaiya-lal-kapil-mishra-jagdish-pradhan-muslims Last accessed September 1, 2020.

Mishra, Pankaj, 2018, Age of Anger. A History of the Present, London, Penguin.

Mody, Anjali, 2020, "In photos: fourteen Delhi mosques and a dargah that were burnt by Hindutva vigilantes in three days," Scroll.in, March 12. URL: https://scroll.in/article/955713/in-photosfifteen-muslim-shrines-in-delhi-that-were-burnt-by-hindutva-vigilantes-in-three-days Last accessed September 1, 2020.

Mubayi, Vinod, 2020, "After Losing Delhi Election, BJP Wreaking Vengeance On City's Minorities," Alternatives international, Feb. 29. URL: www.alterinter.org/?After-Losing-Delhi-Election-BJPWreaking-Vengeance-On-City-s-Minorities Last accessed September 1, 2020.

Ostermann, Susan, and Amit Ahuja, 2018, "Institutional Tug of War: The Election Commission in a Time of Executive Resurgence," CASI, July 16. URL: https://casi.sas.upenn.edu/iit/ostermannahuja Last accessed May 2, 2020.

Rashid, Omar, 2020, "11 FIRs under U.P. ordinance so far," The Hindu, December 21. URL:www.thehindu.com/news/national/other-states/11-firs-under-up-ordinance-so-far/article33380 361.ece? Last accessed May 2, 2021.

Sachdev, Vakasha, 2020, "Justice Muralidhar Will Not Continue Hearing Hate Speech FIR Case," The Quint, Feb. 26. URL: www.thequint.com/news/law/justice-muralidhar-delhi-violence-fir-case-hatespeech-transferred-chief-justice-high-court Last accessed May 2, 2021.

Sen, Sumant and Naresh Singaravelu, 2020, "Data | How many people died during anti-CAA protests? How many people died during anti-CAA protests?" The Hindu, January 6, 2020. URL: www.thehindu.com/ data/data-how-many-people-died-during-anti-caa-protests/article30494183.ece Last accessed August 27, 2020.

Shamshad, M.R., Gurminder Singh Matharu, Tehmina Arora, Tanvir Kazi, Haseena Hashia, Abu Bakr Sabbaq, Salem Baig, Devika Prasad, and Aditi Dutta, 2020, Report of the DMC fact-finding Committee on North-East Delhi Riots of February 2020, Delhi, Delhi Minorities Commission, Government of NCT of Delhi. URL: https://ia601906.us.archive.org/11/items/dmc-delhi-riot-fact-report-2020/-Delhiriots-Fact-Finding-2020.pdf Last accessed August 31, 2020.

Shroff, Kaushal, 2020a, "Men in uniform torched Mustafabad's Farooqia Masjid, assaulted people inside: Locals," The Caravan, March 11. URL: https://caravanmagazine.in/conflict/men-in-uniformtorched-mustafabads-farooqia-masjid-assaulted-people-inside-locals Last accessed September 1, 2020.

Shroff, Kaushal, 2020b, "Delhi violence: Cops shouted 'Jai Shri Ram' with armed Hindu mob, charged at Muslims," The Caravan, Feb. 25. URL: https://caravanmagazine.in/conflict/delhi-violence-copsshouted-jai-shri-ram-with-armed-hindu-mob-charged-at-muslims Last accessed October 3, 2020.

Siddique, Iram, 2021, "3 months of MP 'love jihad' law: 21 cases, couple knew each other in over half," The Indian Express, 20 March. URL: https://indianexpress.com/article/india/mp-love-jihad-law7236429/ Last accessed May 2, 2021. 


\section{Christophe Jaffrelot}

Sidiq, Nusrat, 2020, "Kashmir's mineral contracts largely handed to non-locals," Asia Pacific, July 27. URL: www.aa.com.tr/en/asia-pacific/kashmir-s-mineral-contracts-largely-handed-to-non-locals/ 1923634 Last accessed September 3, 2020.

Singh, Prabhijit, 2020, “Dead and buried,” The Caravan, June 21. URL: https://caravanmagazine.in/politics/ delhi-police-ignored-complaints-against-kapil-mishra-bjp-leaders-leading-mobs-delhi-violence Last accessed 2 May, 2020.

Smooha, Samy, 2002, "The model of ethnic democracy: Israel as a Jewish and democratic state," Nations and Nationalism, 8(4).

Srivastava, Piyush, 2019, “One student's hand had to be amputated, Bared: Police 'brutality' on AMU students," The Telegraph, Dec. 18. URL: www.telegraphindia.com/india/bared-police-brutality-onamu-students/cid/1728324 Last accessed August 27, 2020.

The Economic Times, 2019, "Protests erupt across India over CAA, police action against Jamia students," The Economic Times, Dec. 16. URL: https://economictimes.indiatimes.com/news/politics-andnation/from-lucknow-to-hyderabad-protests-across-campuses-against-police-crackdown-in-jamia/ articleshow/72743549.cms?from $=$ mdr Last accessed May 2, 2020.

The Hindu Special Correspondent, 2020, "At least 60 injured in police crackdown at Aligarh Muslim University," The Hindu, Dec. 15, 2019. URL: www.thehindu.com/news/national/students-injured-inpolice-crackdown-at-aligarh-muslim-university/article30313968.ece Last accessed August 27, 2020.

The Telegraph Staff Reporter, 2019, “"No Hindu will have to leave over NRC', The Telegraph, Sept. 22. URL: www.telegraphindia.com/west-bengal/no-hindu-will-have-to-leave-over-nrc/cid/1706854 Last accessed August 26, 2020.

The Wire Staff, 2020, "In LS Debate on Delhi Riots, Amit Shah Lauds Police for "Controlling Violence in 36 Hours'," The Wire, March 11. URL: https://thewire.in/communalism/lok-sabha-delhi-riotsamit-shah Last accessed September 1, 2020.

Yadav, Anumeha, 2020, "Ground Report: Delhi Police Actions Caused Death Of Man In Infamous National Anthem Video," Huffpost, March 2. www.huffpost.com/archive/in/entry/delhi-riots-policenational-anthem-video-faizan_in_5e5bb8e1c5b6010221126276 Last accessed September 7, 2021.

Yadav, Shyamlal, 2018, “Agra a blip, RSS to step up 'ghar wapsi'," The Indian Express, December 11, 2014. URL: http://indianexpress.com/article/india/india-others/agra-a-blip-rss-to-step-up-ghar-wapsi/ Last accessed April 25, 2018.

Yiftachel, Oren, 1997, “'Israeli Society and Jewish-Palestinian Reconciliation': Ethnocracy and Its Territorial Contradictions'," Middle East Journal 51(4), pp. 505-519.

Yiftachel, Oren, 2006, Ethnocracy: Land, and the Politics of Identity Israel/Palestine, Philadelphia, Penn Press.

Zargar, Safwat and Ipsita Chakravarty, 2020, "A year of government policies that eroded hard-won land rights in Jammu and Kashmir," Scroll.in, August 4, 2020. URL: https://scroll.in/article/969275/ayear-of-government-policies-that-eroded-hard-won-land-rights-in-jammu-and-kashmir Last accessed September 3, 2020. 